\title{
Meritocracy and competency-based people management model: utopia or organizational reality?
}

\author{
ALMIR ROgÉRIO dA SILVA SOUZA ${ }^{1}$ \\ ISABELLA Francisca Freitas GoUveia de VASCONCELOS ${ }^{2}$ \\ ${ }^{1}$ AUtONOMOUS RESEARCHER, RIO DE JANEIRO - RJ, BRAZIL \\ ${ }^{2}$ AUtONOMOUS RESEARCHER, CAMPINAS - SP, BRAZIL
}

\begin{abstract}
Our literature review is based on the definition of meritocracy in contemporary societies and organizations. We relate meritocracy to competency-based people management model (strategic people management model), where clear objectives and goals are defined transparently with teams and individuals, and conducting performance evaluation according to previously established criteria. When merit is determined, it is recognized both symbolically and through differentiated remuneration for individuals and teams. It is emphasized that a meritocratic system and competence management reinforces the sense of social justice in organizations and equity and trust relations in the system. The research consisted of a survey with 17 executives, students of a master's degree program in business administration offered by a teaching organization of excellence. Results showed that $53 \%$ of them consider their companies meritocratic, $36 \%$ considered their companies partially meritocratic, and $11 \%$ consider that the organization they work for does not recognize meritocracy. The study discusses these results, proposing solutions for the improvement of people management systems.
\end{abstract}

Keywords: Meritocracy. Equity. Competency-Based People Management Model. Trust.

\section{Meritocracia e gestão de pessoas por competências: tema utópico ou realidade organizacional?}

\section{Resumo}

Neste trabalho se realiza uma revisão de literatura sobre o valor meritocracia nas sociedades contemporâneas e nas organizações. Relacionamos o valor meritocracia a um modelo de gestão de pessoas baseado em competências (modelo estratégico de gestão de pessoas), onde são definidos objetivos e metas claras de forma transparente com equipes de trabalho e indivíduos e realizada uma avaliação de desempenho segundo critérios claros previamente estabelecidos e, quando apurado o mérito, o mesmo é reconhecido com base em remuneração diferenciada para indivíduos e equipes, além de ser reconhecido o mérito de forma simbólica. Ressalta-se que um sistema meritocrático e uma gestão por competências reforçam o sentimento de justiça social nas organizações e equidade e as relações de confiança no sistema. Depois de realizada uma pesquisa, onde foram entrevistados 17 executivos alunos do Mestrado Profissional em Administração, em uma organização de ensino de excelência, constatou-se que 53\% dos mesmos trabalham em empresas consideradas meritocráticas por eles e $36 \%$ em empresas parcialmente meritocráticas e 11\% em empresas onde não existe nenhum reconhecimento de mérito. Analisaram-se as causas destes resultados, propondo-se soluções para o aprimoramento destes sistemas.

Palavras-chave: Meritocracia. Equidade. Gestão de Pessoas por Competências. Confiança.

\section{Meritocracia y gestión de personas por competencias: ¿ tema utópico o realidad organizativa?}

\section{Resumen}

En este trabajo se realiza una revisión de la literatura sobre el valor meritocracia en las sociedades contemporáneas y en las organizaciones. Relacionamos el valor meritocracia con un modelo de gestión de personas basado en competencias (modelo estratégico de gestión de personas) donde se definen objetivos y metas claras de manera transparente con equipos de trabajo e individuos y se realiza una evaluación de desempeño de acuerdo con criterios claros previamente establecidos y, una vez determinado el mérito, se reconoce mediante una remuneración diferenciada a individuos y equipos, además del reconocimiento simbólico. Se enfatiza que un sistema meritocrático y una gestión por competencias refuerzan el sentido de justicia social y equidad en las organizaciones y las relaciones de confianza en el sistema. Después de realizar una encuesta con 17 ejecutivos, alumnos del máster profesional en Administración de Empresas de una organización de enseñanza de excelencia, se constató que el 53\% considera que trabaja en empresas meritocráticas; el 36\%, en empresas parcialmente meritocráticas; y el 11 \% en empresas donde no hay reconocimiento de mérito. Se analizaron las causas de estos resultados y se propusieron soluciones para la mejora de estos sistemas.

Palabras clave: Meritocracia. Equidad. Gestión de personas por competencias. Confianza. 


\section{INTRODUCTION}

This article discusses and analyzes the perspective of executive officers on the use of the competency-based management model and its real contribution to meritocracy in their organizations.

Meritocracy has theoretical bases and finds empirical support in current organizational theories. It is not an easy topic to discuss, involving interconnected and constantly analyzed factors to assess the effectiveness of its applicability.

This study recognizes the controversies around meritocracy and the importance of reflecting on the topic. The article explores whether there is meritocracy in Brazilian organizations considering the current times of institutional economic and moral crisis.

\section{Strategic management of people and competencies}

The strategy has currently played a leading role within organizations and their areas, mainly in elaborating processes and means to achieve organizational development, aligning all the actors in the context. Therefore, strategic people management has a key role considering the importance of individuals and their daily work in organizational development, a process that involves coordinating interests, increasing motivation, and developing incentives based on merit, so that the individual is engaged in meeting the organizational goals (Zanini, 2009).

Competency is related to how to use intelligence to develop the knowledge acquired through combining and transferring resources able to generate economic value for organizations and social value for the individual. Competency intends to produce solutions to specific challenges (Fleury, 2002; Zarifian, 1999).

The concept of competency can encompass the notion of delivery. According to Dutra (2001), competency involves the individual's knowledge, skills, and attitude, while delivery refers to elements that the individual wants to offer responsibly to the organization. Amid the discussion on competency, it is worth to reflect whether it makes sense to address the issue of meritocracy.

\section{Meritocracy}

At the ideological level, meritocracy is a set of values that lead individuals to seek their position in society through personal actions and efforts. It is the public recognition of the individual's self-actualization capacity (Barbosa, 2003).

It is a highly complex topic within the Brazilian organizational culture, widely debated in the academic literature. The discussions on meritocracy affect (objectively or subjectively) the analysis regarding the concept's depth and extent. It is also seen as a management and evaluation system to obtain gains based on a particular outcome of a task performed, and that can also be used to ascend the organizational hierarchy.

Merit is a way of equally offering any individual the opportunity to stand out in a group when demonstrating production capacity through intelligence, talent, and commitment, considering the personal strength to achieve goals above the expectation. The idea stands in opposition to the notion that opportunities should be offered based on the individual social class or family inheritance.

\section{Meritocratic systems and the ideology of meritocracy}

An egalitarian society emerges based on preserving rights that enable free and equal individuals - regardless of classes, genders, and ethnicity, for example - to achieve success and recognition. A form of guaranteeing meritocracy in the organization is to offer people equal access to opportunities and conditions for social advancement to overcome difficulties and achieve goals using their own means and intrinsic characteristics (Barbosa, 2003; Bobbio, 1997). 
Based on this ideology, any individual who stands out within a social group is recognized - through merit and can gain a position within that group. The individual then accesses a higher position or role, with more attributions and responsibilities, a better benefits package, reputation, and functional status.

This policy may influence those who have not yet obtained distinction, exerting a motivating force by showing that merit and personal effort are necessary to achieve success. The meritocratic ideology is validated through the isonomy of evaluation and recognition.

Equity is a condicio sine qua non to a democratic rule of law system, i.e., where all members of a society have the same rights under the law. For this reason, a meritocratic system has so much strength and is an indispensable attribute of a democratic society. It offers all individuals the same chances of standing out within well-known and previously established criteria. The system rejects any possibility of maintaining access to opportunities for a small and protected group, which often does not meet the pre-established minimum criteria.

A question always surrounds the meritocratic process: How can we ensure that everyone has the same conditions for socio-cultural development and that only intrinsic skills and competency are evaluated in the competition process?

Transparency throughout the process is crucial, and equity is an absolute value for verifying the entire evaluation process in a real and isonomic way. Thus, merit would be the only way of breaking ties. In modern and egalitarian societies, meritocracy is an essential system to achieve the individual's goals and desires (Barbosa, 2003), rejecting forms of oppression and pressure (proximity, hierarchy, and influence). Would meritocracy be a "utopian" ideology nowadays?

\section{Meritocracy and competency-based people management}

There is the hypothesis that the introduction of competency-based people management in an organization may privilege meritocracy. This would occur because of organizational practices since competency is a form of evaluating the individual.

Barney (1991) proposed the resource-based view (RBV), supported by the definition that contemporary organizations can be considered a set of resources. These resources (financial, physical, human, and organizational capital), in a globalized world, are no longer a competitive differential. The differential is a competitive advantage that the competition has difficulties imitating. Therefore, competitive advantages that are copied by the competition are no longer advantages.

Barney's model finds synergy with the concept of core competencies by Prahalad and Hamel (1990), where an organization must develop competencies that must be difficult to imitate by the market.

The core competencies work as a foundation for the organization's competitive advantage in its various areas of operation, where a change in any (internal or external) scenario requires an organizational change or adaptation (known as dynamic capability) (Leonard-Barton, 1992). Competitive advantage can be obtained through innovation, where the configuration of dynamic capabilities can produce innovative and differentiated services and products (Teece, 1992). These changes affect the individuals, as they need to develop new essential skills to perform their activities, acquiring new knowledge, skills, and attitudes.

The processes that create and stimulate personal development in the organization as a form of professional growth are more sensitive to the effect of competence (Dutra, 2004). The evolution of an individual within the organization involves the person's identification with the institution's core competencies and the organization's ability to maintain the individual motivated, considering that institution's ability to work with challenges is directly linked to its capacity to have an active and real meritocratic system with an isonomic performance evaluation. Professionals who stand out the most in the face of organizational changes and deliver the expected results are duly recognized through an award, salary raise, or promotion. It is crucial to have a clear meritocratic system with rules accessible to all organization members, as it reinforces everyone's credibility and confidence in the competency-based management model. 


\section{Trust as the company's intangible assets}

Trust is a valuable intangible asset both in personal and business relationships. Trust occurs in relations between two or more parts - people or organizations.

The social system theory by Luhmann (1996) points out three types of trust: (1) procedural, (2) based on characteristics, and (3) institutional trust.

Trust is an issue observed in the relationships formalized through employment contracts. In this sense, ethically justified behaviors are observed, involving the vertical and horizontal relations between members of an organization. Morally justified relations are also observed, considering the credibility such relations offer to a system or person, expressing good faith in the other, without taking undue advantage in the contracts - which reflect a mutual interest or economic exchange (Cummings \& Bromiley, 1996; Giddens, 1991; Hosmer, 1995; Zanini, 2016).

Trust is an important complement that strengthens corporate interactions. These relations promote cooperation among individuals and coordination between organizational areas. It works as a leadership and people management tool, and the whole environment gains a more productive dynamic. The individuals become more engaged in the organizational culture as the interdependent relationship reduces the risks of confrontation. The organization benefits from more transparent and dynamic processes.

In addition, sociability is a positive feature affecting bureaucracies, which become less tense and more fluid. Organizational processes gain flexibility, and there is cooperation among the individuals within the organizational chain.

Trust is built over time and does not open space for immediacy. It is relational and cultivated by principles of justice and mutual sharing, where two or more parties establish significant interaction and elaborate and agree on norms and assumptions. All of this complexity will influence the organization's decision-making process.

Trust is one of the pillars supporting the ideology of a meritocratic system. The adherence and credibility of merit depend on the actors' commitment, so it is possible to establish a performance evaluation.

There is no isonomy in a meritocratic system where actors do not trust the stipulated rules. There is a need for consensus between the organization and individuals on all rules. If this is not the case, the adherence of the functional groups will not happen, the evaluation process will not be followed and the whole process will fail. A meritocratic system without everyone's trust cannot produce an expected result since some of the individuals are suspicious of the evaluation process.

\section{Trust-based management}

Efficient management needs to work creating conditions to facilitate meeting the expected goals. Building trust is a fundamental condition, considering the individuals' interpersonal relations and how they influence performance.

Studies have demonstrated a correlation between trust and performance. They have focused on individuals involved in the management process, determining the need to expand and deepen on the construct of trust. The studies point out the need to explore its particularities, details, and influence within the organizations (Araujo \& Cançado, 2013; Kawai, 2017; Krot \& Lewicka, 2012; Zanini \& Migueles, 2014).

As for meritocracy, it is worth noting the prominence the construct has gained in social sciences such as sociology, anthropology, psychology, economics, and administration (Fukuyama, 1996; Giddens, 1991; Kramer \& Tyler, 1996; Lane, 1996; Luhmann, 1980; Tzafrir \& Harel, 2002; Zand, 1972; Zanini, 2016).

Leaders and subordinates must share a high degree of trust, given the integration and unity needed to reach the organizational goals. Trust is relational, involving an emotional and cognitive engagement of the actors interacting. It requires a visceral interaction that exceeds the pure logic of reason (Ripperger, 1998; Zanini, 2016). 
Risk-taking cannot be neglected in a trust-based relationship. Trust promotes the solution to the parties' common problems and minimizes possible communication conflicts, particularly communication between organizations and individuals. It is important to point out that trust starts from the idea that a promise will be properly fulfilled, based on someone's loyalty and loyalty in the face of their commitment to the other party (Duluc, 2000).

The interaction between the parties always entails some risk. Ideas that do not count on the commitment from both parties should be disregarded based on the real risks inherent to interactions. Trust required full awareness of risks for all involved parties (Zanini \& Migueles, 2014).

Trust-based management offers paths for an organization to implement a meritocratic system able to produce clear and efficient performance evaluation methods, as the relationships always occur within a social context (Zanini, 2016). All individuals involved in the process of recognition and professional growth must know and trust the rules, evaluations, and final decisions.

\section{Meritocracy and trust}

Meritocracy and trust are long-term investments cultivated in the present and approved by those involved in the relationship. Therefore, everyone is aware of each actor's role in the social context (Barbosa, 2003; Zanini, 2016).

Organizations that have effectively introduced and practice a meritocratic system of professional growth and remuneration inspire trust in the institution and its business beliefs, potentially shortening social differences (Sandel, 2014).

Trust has a preponderant role within a meritocratic system. It is related to the channel through which the individuals and the organization share knowledge and best practices, allowing employees to deliver outstanding performances and obtain professional recognition based on their efforts. Contributions of all actors involved will reflect in the organization as a whole, addressing its demands and needs and generating a valuable intangible asset (Zanini, 2016).

The perception of meritocracy in the organization is reinforced with effective competency-based people management, building trust among individuals at the organization's management and leadership levels. It also reinforces the bonds of trust in the collective work (among different areas or people in the same area).

There is a perception of greater distributive justice at work when a meritocratic system is well applied and accessible to all individuals in the organization.

\section{METHODOLOGY}

This research explores the perspective of a group of executive officers who attend a graduate program in business administration in a renowned higher education institution in Brazil about meritocracy and competency-based people management. The research question guiding the study is: do executive officers consider that their companies apply meritocracy, and is the issue of meritocracy in their company related to the implementation of competency-based people management? This study aims to understand whether, in the executive officers' view based on their career paths, companies are more meritocratic when implementing the competency-based people management model.

According to Godoy (1995a), the concepts of qualitative research reflect four basic characteristics: a) qualitative research has the natural environment as a direct source of data and the researcher as a fundamental instrument; b) qualitative research is descriptive; c) the meaning that people give to things and their life is the essential concern of the researcher; d) Researchers use the inductive approach for data analysis (Godoy, 1995a, pp. 62-63, our translation).

In qualitative studies, documentary research can be a primary source, produced by the people or organizations that experienced the event; or a secondary source, when people or organizations narrating the facts were not present at the time they happened, but the information is still relevant for analysis (Godoy, 1995b). The uniqueness of such studies lies on the field research carried out to collect the data. 
Case study is a form of research that deeply explores an object under analysis, considering the context in real life. It is an empirical research that stresses the limits between the context and the phenomenon, focusing on the dynamic compreension that is present in the data collection methods (Creswell, 2014; Einsenhardt, 1989; Godoy, 1995b; Yin, 2015).

The field research aims to gather data and information on a specific problem in order to prove an hypothesis or find new phenomena that are inherent to the studied object (Marconi \& Lakatos, 2003); This research collected data from a primary source through semi-structured interviews adjusted according to the evolution of the analysis of the material collected. The script worked as a guideline, but interviewees were free to add information they deemed necessary and relevant.

The interviewees were approached in a Professional Master in Administration offered by a renowned Brazilian higher education institution, a pioneer in implementing administration programs in Brazil. The participants shared the same socio-cultural profile and were students attending the program. They were executive officers working in large national and international companies that adopt competency-based people management and where meritocracy is already part of their regular performance appraisals.

Initially, 30 students from the mentioned professional master were invited to participate as interviewees. They were approached personally or via social media. Some of the executives invited declined the invitation, arguing that they preferred not to expose their organization or themselves despite the anonymity.

Of the 30 students contacted, 23 agreed to participate. However, after the first contact, 19 confirmed the interest, and only 17 students dedicated the time to schedule and carry out the interview. For the purpose of research ethics, the names of the interviewees are not disclosed, maintaining anonymity.

Finally, the analysis conducted is interpretative, i.e., it is not neutral or impartial. The researchers kept a distance when interpreting the data and events expressed during the interview, but the interaction, considering the phenomenological knowledge, entails a certain degree of partiality in the analysis, which is one of this research's limitations.

\section{PRESENTATION OF DATA}

Semi-structured interviews were conducted with 17 participants from June 22 to July 25, 2017, live and via Skype, all of which were recorded and transcribed in full to facilitate the analysis.

Each interviewee received a code to maintain anonymity, and after completing the interviews, five profiles were stipulated: (1) age; (2) education; (3) training; (4) job title/function, and (5) gender.

The data collected after the interviews were used to form five categories based on the research scope (Box 1): 
Box 1

Categories and meanings

\begin{tabular}{|c|l|}
\hline Categories & \multicolumn{1}{c|}{ Meanings } \\
\hline Category 1 & $\begin{array}{l}\text { Importance of the Master Program in the Interviewee's Career } \\
\text { (opinion about the program) }\end{array}$ \\
\hline Category 2 & $\begin{array}{l}\text { Interviewee's opinion on Meritocracy (concept and vision within } \\
\text { the company) }\end{array}$ \\
\hline Category 3 & $\begin{array}{l}\text { Interviewee's opinion on the company's Competency-Based } \\
\text { Management }\end{array}$ \\
\hline Category 4 & $\begin{array}{l}\text { Interviewee's opinion on Meritocracy in the company (what can } \\
\text { be improved) }\end{array}$ \\
\hline Category 5 & Interviewee's opinion on Trust in the company's meritocratic system \\
\hline
\end{tabular}

Source: Elaborated by the authors.

For each interview, a file was created based on the categories previously determined based on the data analysis.

\section{INTERVIEW ANALYSIS AND GROUPS}

After the files' analysis, four groups were identified:

\section{Group 1 - Interviewees 01, 02, and 07}

Opinion: Meritocracy and competency-based management are present in their speech. However, the interviewees perceive injustice in the calculation of the remuneration (bonus) and in how the symbolic merit is attributed. The group perceives injustice and extreme competition among individuals.

They believe that meritocracy is correlated to competency-based people management. The group represents approximately $18 \%$ of the interviewees. From their point of view, their companies partially apply a meritocratic system, using a Harvard's forced curve in their performance concepts ( $\mathrm{A}-20 \%$ of the employees are considered the best; $\mathrm{B}-30 \%$ are considered very good; $C-20 \%$ are considered good; $D-15 \%$ are moderately good, and $E-15 \%$ do not receive any bonuses because they did not manage to meet the expected results).

\section{Group 2 - Interviewees 03, 06, 08, 10, 11, 13, 14, 16, and 17}

Opinion: These interviewees believed in meritocracy combined with competency-based people management in organizations. They work in organizations that apply meritocracy as a way of evaluating performance and gaining trust. There is a greater perception of justice in the face of the methods applied by everyone involved in the organization.

There are clear and objective rules in the organizations. All employees can access the opportunities and means to achieve meritocratic acknowledgment based on the person's delivery capacity. Professionals are recognized through extra bonuses, salary increases, formal recognition within the organization. The feeling and perception of justice are present and are inherent to everyone being evaluated.

A detail that draws attention is that $78 \%$ of respondents in this group are over 30 years old and hold management and board positions in large companies. This group represents 53\% of respondents. Adding groups 1 and 2, 71\% of the interviewees work in meritocratic or partially meritocratic companies. 


\section{Group 3 - Interviewees 04, 12, and 15}

Opinion: This group recognizes that meritocracy is correlated with competency-based people management. They work in companies where the construct meritocracy is disseminated with rules and appraisals. However, the experience in the daily activities is marked by promotion and recognition based on friendship or politics.

The interviewees work in a state-owned company in the oil and gas industry and in a private family company. This management practice ends up being corrosive because it weakens meritocracy as a form of increasing engagement toward results. What is important is who recommends who when there is a promotion opportunity instead of recognition for excellent professional performance and awards for achievements. This group consists of $18 \%$ of respondents.

\section{Group 4 - Interviewees 05 and 09}

Opinion: This group consists of skeptic executive officers. They do not believe in meritocracy and find the theme utopic and idealistic, especially in Brazilian organizations. From their point of view, meritocracy is not applied, although it is often mentioned in speeches and the company's narratives. They work in unions and state-owned companies in the energy industry and do not believe that professionals receive proper recognition.

\section{DATA ANALYSIS}

This work considers merit as associated with the effort to achieve specified results between the organization's leadership and each employee. According to the interviews, it is not enough for the company to have a strategic people management system or a competency-based system, even if such arrangement is well structured - well-established performance appraisals, goal setting with the work teams in a transparent and well-defined manner, and a coherent assessment system to determine whether goals have been achieved. Although this type of system is necessary, it is not sufficient to generate a feeling of fairness and justice among employees, which would generate a positive cycle, where employees would dedicate themselves more and more to the company for perceiving a fair and correct system based on merit, which would further increase productivity.

The feeling of fairness in the organization is crucial to generate a virtuous cycle, recognizing employees who work hard to meet or exceed their goals. According to the interviewees, the calculation of remuneration based on productivity and how the company chooses to pay such remuneration is crucial in building this feeling of fairness.

For group 1, their company made a huge investment to have a strategic and competency-based people management system, having structured a coherent career plan, a clear and logical method of setting targets and goals with teams and individuals, and determining whether the result was achieved. However, all this effort does not generate the feeling of fairness and the desired virtuous cycle. There is a perception of a system based on transparently verifying the merit of individuals, but within a system that distributes rewards unfairly. According to the interviewees, the way of calculating the payment for meeting goals and the form of attributing symbolic recognition are unfair. These methods are unequal and force the division of the employees using Harvard's forced curve, perceived as bringing inequality and a feeling of injustice.

The interviewees observed that the companies invested in having competency-based management and a meritocratic and professional system. However, these investments result in dissatisfaction and perception of inequality since they did not manage to offer appropriate recognition (symbolic or through remuneration). Thus, the company did not achieve its goals with the investment in such systems, frustrating the expectation of having engaged and productive employees identified with the organization's values in an environment of fairness and trust relations. The employees suggest the companies should change the form of payment and attribution of symbolic recognition, no longer calculating according to the forced curve and seeking other more equitable methods of translating goals into remuneration. When calculating the bonuses, the company could fix percentages of the individuals' salaries or even a certain number of salaries to be received by each team or by each individual, which would generate the perception of greater equality and equity in the distribution of benefits, as the differentiated salaries already allow differentiation in individual recognition. 
For group 2,53\% of the interviewees have a perception of fairness and meritocracy in the company in which they work, generating the virtuous cycle that reinforces the relationships of trust in the system. We find here a correlation with the people management theory. In addition to a system consistent with setting targets and goals with teams and individuals and determining results transparently and clearly, the payment for merit and symbolic recognition occurs in a way that is perceived as more equitable. Those who meet the targets, those who meet and exceed them, and those who did not, are identified, and a number of times the salary ( 2 times, 3 times the employee's salary, for example) is calculated as a bonus to be received. As salaries vary among employees, the bonuses are automatically differentiated, and this system is perceived as fairer. These companies also offer pay raises according to the company's growth.

Similar to the study by Zanini (2016), the case of group 2 shows us that systemic trust (the degree of reliability that an individual or group of individuals perceives in a given social system, such as an organization) increases. Remuneration and attribution of symbolic recognition are perceived as fair and equitable, considering the due differences.

Thus, by adopting a meritocratic system, trust-based management offers an organization the means to develop efficient performance assessment tools and professionals involved in any professional growth process to trust the rules, assessments, and final decisions.

As defined in this work, global executives hold positions in large multinational companies that have highly qualified professionals and well-defined people management processes. They work with people of different nationalities, speak several languages, deal with cultural diversity, hold management positions, travel and coordinate international teams, and have a high remuneration.

These executives belong to an elite that makes big decisions and is socio-economically influential. Often called the technocratic elite because of their high-level professional training, they mostly work in the private sector.

Half of the interviewees are high-qualified executive officers who work in companies they consider fair and meritocratic, which suggests they are employees enjoying a favorable professional condition.

However, group 1 points out that, although the company has a formalized competency-based management system that transparently and consistently calculates merit, there is no perception of social justice and generation of the virtuous cycle of increasing productivity and reinforcement of trust relationships due to the forced curve system to calculate remuneration and symbolically attribute merit. The interviewees suggest that the companies should change how they calculate merit remuneration, avoiding the forced curve system. There are three respondents in this group.

Group 3 points out the existence of competency-based management of the strategic people management model, and the payment and attribution of merit are considered fair, but only up to a certain managerial level. From this hierarchical level, promotions are perceived as being due to political criteria and linked to personalistic criteria. The three interviewees in this group work either in large state-owned companies, where there is competitive hiring processes, remuneration for performance, and also many employees in appointed to positions (political criteria); or in family businesses, where the owners' relatives are placed in the organization's higher positions. The perception of the interviewees (two of whom are global executives) is that meritocracy somehow fits in this type of system, even though sharing space with personalistic criteria influencing the career paths.

In group 4, the two interviewees are skeptical about the country and think that the problem is systemic in Brazil, especially at this historical moment, where the country is experiencing an economic and political crisis. It is a moment where all values are questioned in the fight against corruption, and it is observed that we are not living a reality based on merit, neither in the public sector nor in the private sector, and people are only concerned with surviving. Of the two interviewees, one works in a union and the other in a large state-owned energy company. 
Box 2

Groups and typology

\begin{tabular}{|c|c|c|}
\hline Groups & Interviewees & Typology \\
\hline Group 1 & $101 ; 102 ; 107$ & $\begin{array}{l}\text { Meritocracy is correlated to competency-based people management, transparent performance } \\
\text { assessment, differentiated payment according to performance, and fairness. They believe } \\
\text { that organizational transparency is crucial. They perceive meritocracy in their companies } \\
\text { but do not see justice because of Harvard's forced curve (A - 20\%; B - 30\%; C- 20\%; } \\
D-15 \% \text { and E-15\%, where outstanding performance is not appropriately recognized). }\end{array}$ \\
\hline Group 2 & $\begin{array}{l}\text { 103; 106; } 108 \text { I10; I11; } \\
\quad \text { I13 I14; I16; I17 }\end{array}$ & $\begin{array}{l}\text { They recognize that meritocracy is correlated to competency-based management and } \\
\text { performance assessment using explicit and transparent criteria and previously established } \\
\text { goals. Meritocracy and perception of justice exist in their company because everyone } \\
\text { receives the same number of extra-salaries as a bonus if they reach the targets. }\end{array}$ \\
\hline Group 3 & $104 ;|12 ;| 15$ & $\begin{array}{l}\text { They admit that meritocracy is related to competency-based management do not perceive } \\
\text { fairness in their company. For them, most promotions occur based on a personalistic criterion. }\end{array}$ \\
\hline Group 4 & $105 ; 109$ & $\begin{array}{l}\text { They are skeptical and do not believe in meritocracy. Find it a fanciful concept, especially } \\
\text { in Brazil. }\end{array}$ \\
\hline
\end{tabular}

Source: Elaborated by the authors.

\section{Response to the research question}

The research question was concerned with whether, according to the executives interviewed, meritocracy existed in the companies where they work and whether this would be related to the implementation of competency-based people management in their company. The assumption of meritocracy and trust was confirmed in $53 \%$ of the interviews (group 2).

In companies that have fully implemented the concept and practice a meritocratic system of promotion and remuneration, there is greater trust in the organization. Therefore, a more effective competency-based people management (including the formula for calculating the remuneration that does not obey a forced curve logic) reinforces the perception of meritocracy in the company, generating greater trust among employees in different hierarchical positions.

Usually in this type of system, employees have a perception of greater distributive justice at work, as was the case for $53 \%$ of the interviewees. In $36 \%$ of cases (groups 1 and 3 ) there is a partial meritocratic system linked to management by competencies, but which still needs to be improved to generate a greater perception of distributive justice at work.

For $11 \%$ of the interviewees (group 4), there is currently no perception of meritocracy in Brazil given the historical moment in which the country lives. This group is considered skeptical.

Finally, $89 \%$ of the interviewees do not agree with the perception of group 4. Most executive officers recognize that there are meritocratic systems in the country and the companies they work in. These systems need improvement to a greater or lesser degree, but they are perceived as meritocratic systems. 


\section{CONCLUSION}

Resuming the theoretical part of this study, we conclude with the following considerations:

\section{About meritocracy}

The perception of meritocracy was identified since most interviewees (89\%) believe that the construct is partially or entirely institutionalized in their companies. For $53 \%$ of the interviewees, they are working in satisfactorily meritocratic systems.

\section{Ideology of meritocracy}

For the interviewees, a form of addressing the current socio-economic crisis in Brazil lies in developing a society that provides more equal conditions, fairer in distributing public investments, and more meritocratic access to opportunities. They believe that such characteristics can be put forward through investment in education and improving competency-based people management systems in private and public entities, focusing on capacity building and creating more efficient models. For the interviewees, it is necessary to establish a competency-based management model that recognizes merit in a real and effective way, seeking social justice in the various spheres of private and public organizations and improving life quality and professional relations. The movement around Operation Car Wash - a nationwide corruption investigation involving public and private organizations conducted under the leadership of former judge and former-minister Sergio Moro - has had an important role in recovering the trust in Brazilian public and private institutions. Such events contribute to institutionalizing meritocracy and organizational transparency, supporting the development of fairer organizations (Dallagnol, 2017; Hasselmann, 2016; Netto, 2016). 


\section{REFERENCES}

Araujo, J. B. C., \& Cançado, V. L. (2013). Confiança e desempenho de equipes. Revista Eletrônica de Ciência Administrativa, 12(1), 75-91.

Barbosa, L. (2003). Igualdade e meritocracia: a ética do desempenho nas sociedades modernas. Rio de Janeiro, RJ: Editora FGV.

Barney, J. (1991). Firm resources and sustained competitive advantage. Journal of Management, 17(1), 99-120.

Bobbio, N. (1997). Igualdade e liberdade (2a ed.). Rio de Janeiro, RJ: Ediouro.

Creswell, J. W. (2014). Investigação qualitativa e projeto de pesquisa: escolhendo entre cinco abordagens. Porto Alegre, RS: Penso Editora.

Cummings, L. L., \& Bromiley, P. (1996). The organizational trust inventory. In R. Kramer, \& T. R. Tyler (Eds.), Trust in organizations: frontiers of theory and research. Thousand Oaks, CA: Sage.

Dallagnol, D. (2017). A luta contra a corrupção: a Lava Jato e o futuro de um país marcado pela impunidade. Rio de Janeiro, RJ: Sextante.

Duluc, A. (2000). Liderança e confiança: desenvolver o capital humano para organizações competitivas. Lisboa, Portugal: Instituto Piaget.

Dutra, J. S. (2001). Gestão por competências: um modelo avançado para o gerenciamento de pessoas. São Paulo, SP: Editora Gente.

Dutra, J. S. (2004). Competências: conceitos e instrumentos para a gestão de pessoas na empresa moderna. São Paulo, SP: Atlas.

Eisenhardt, K. M. (1989). Building theories from case study research. Academy of Management Review, 14(4), 532-550.

Fleury, M. T. L. (2002). A gestão de competência e a estratégia organizacional. In M. T. L. Fleury (Ed.), As pessoas na organização (3a ed.). São Paulo, SP: Editora Gente.

Fukuyama, F. (1996). Confiança: as virtudes sociais e a criação da prosperidade. Rio de Janeiro, RJ: Rocco.

Giddens, A. (1991). As consequências da modernidade. São Paulo, SP: UNESP.

Godoy, A. S. (1995a). Introdução à pesquisa qualitativa e suas possibilidades. RAE - Revista de Administração de Empresas, 35(2), 57-63.

Godoy, A. S. (1995b). Pesquisa qualitativa: tipos fundamentais. $R A E-$ Revista de Administração de Empresas, 35(3), 20-29.

Hasselmann, J. (2016). Sérgio Moro - A história do homem por trás da operação que mudou o Brasil. São Paulo, SP: Universo dos Livros Editora.

Hosmer, L. T. (1995). Trust: the connecting link between organizational theory and philosophic ethics. Academy of Management Review, 20(2), 379-403.

Kawai, R. M. (2017). Indicadores de desempenho em uma pequena empresa que adota um modelo de gestão baseado na confiança. Revista da Micro e Pequena Empresa, 11(1), 123- 138.
Kraemer, R. M., \& Tyler, T. R. (1996). Trust in organizations: frontiers of theory and research. Thousand Oaks, CA: Sage.

Krot, K., \& Lewicka, D. (2012). The importance of trust in manageremployee relationships. International Journal of Electronic business Management, 10(3), 224-233.

Lane, C. (1996). Theories and issues in the study of trust. In C. Lane, \& R. Bachamann (Orgs.), Trust within and between organizations: compectual issues and empirical applications. New York, NY: Oxford University Press Inc.

Leonard-Barton, D. (1992). Core capabilities and core rigidities: A paradox in managing new product development. Strategic management journal, 13(S1), 111-125.

Luhmann, N. (1980). Trust: a mechanism for the reduction of social complexity. In N. Luhmann (Ed.), Trust and power. New York, NY: Wiley.

Luhmann, N. (1996). Confianza. Barcelona, España: Antropos.

Marconi, M. A., \& Lakatos, E. M. Fundamentos de metodologia científica (5a ed.). São Paulo, SP: Atlas, 2003.

Netto, V. (2016). Lava Jato: o juiz Sergio Moro e os bastidores da operação que abalou o Brasil. Rio de Janeiro, RJ: Primeira Pessoa.

Prahalad, C. K., \& Hamel, G. (1990). The core competence of the corporation. Harvard Business Review.

Ripperger, T. (1998). Okonomik des vertauens. Tubingen, Deutschland: Mohr Siebeck.

Sandel, M. J. (2014). Justiça: o que é fazer a coisa certa (13a ed.). Rio de Janeiro, RJ: Civilização Brasileira.

Teece, D. (1992, June). Competition, cooperation and innovation: organizational arrangements for regimes of rapid technological progress. Journal of Economic Behavior and Organization, 1, 1-25.

Tzafrir, S. S., \& Harel G. H. (2002). Trust-me: a scale form measuring manager employer trustworthiness. Academy of Management Review.

Yin, R. K. (2015). Estudo de caso: planejamento e métodos (5a ed.). Porto Alegre, RS: Bookman.

Yin, R. K., \& Migueles, C. P. (2014). O papel mediador entre confiança e desempenho organizacional. Revista de Administração, 49(1), 45-58.

Yin, R. K., \& Migueles, C. P. (2016). Confiança: o principal ativo intangivel de uma empresa (2a ed.). Rio de Janeiro, RJ: FGV Editora.

Zand, E. E. (1972). Trust and managerial problem solving. Administrative Science Quarterly, 17(2), 229-239.

Zanini, M. T. F. (2009). A liderança eficaz - contexto brasileiro. In C. Migueles, \& M. T. F. Zanini (Org.). Liderança baseada em valores: caminhos para a ação em cenários complexos e imprevisíveis. Rio de Janeiro, RJ: Elsevier.

Zarifian, P. (1999). Objectif compétence. Paris, France: Liaissons. 
Doctorat es Sciences de Gestion, HEC-Ecole des Hautes Etudes Commerciales, France (2000); Ph.D. in Human Resources Administration, FGV EAESP

(1997); Postdoctoral fellow at Rutgers, the New Jersey State University; Researcher at CNAM - Conservatoire National D’Arts et Metiers, France.

E-mail: ivasconcelos@yahoo.com 